\title{
Religious Politics in Africa: Fasting for Politics, or Political Fasting in Zimbabwe?
}

\author{
Joram Tarusarira \\ University of Groningen, The Netherlands \\ j.tarusarira@rug.nl
}

\begin{abstract}
In the post-colonial history of presidential aspirants in Zimbabwe, no politician has been as overtly religious as Nelson Chamisa, the current leader of the Movement for Democratic Change (MDC). Chamisa identifies himself as a politician and a pastor whose politics are guided by his Christian faith. However, he took religious rhetoric to mobilise support to an unprecedented level when he explicitly blurred the boundaries between functions by calling for and leading a week of fasting and prayer from 29th July to 4th August 2019. Through a digital ethnography of Chamisa's Twitter posts and the direct responses to them posted by members of the public during the fasting and prayer week, this article investigates how this call was received by those who responded on Twitter and what this tells us about Zimbabweans' perceptions of religious politics, that is, the deployment of dominant religions like Christianity in politics.
\end{abstract}

\section{Keywords}

religion - politics - Nelson Chamisa - Zimbabwe - prayer

\section{$1 \quad$ Introduction}

In the post-colonial history of presidential aspirants in Zimbabwe, no politician has been as overtly religious as Nelson Chamisa, the current leader of the Movement for Democratic Change (MDC). Chamisa, who studied law and political science at the University of Zimbabwe and theology at a local theological school, identifies himself as a politician and a pastor whose politics are guided by his Christian faith. A former member of parliament and cabinet 
minister from February 2009 to July 2013, Chamisa has held numerous posts in the MDC, including chair of the national youth assembly, spokesperson of the party and organizing secretary. In 2016, he was appointed to serve as one of the three vice-Presidents of the MDC. Upon the death of Morgan Tsvangirai, the founding President of the MDC, the party's national council appointed him as its president. ${ }^{1}$

The interaction between religion and politics in Zimbabwe has not lacked debate. From the liberation struggle of the 1960 os to the present, politicians have always deployed religious rhetoric to mobilise support. However, Chamisa took this to an unprecedented level by explicitly blurring the boundaries between his functions as politician and pastor by calling on Twitter for and leading a week of fasting and prayer from 29th July to 4th August 2019.

This article investigates how this call was received by those who responded on Twitter and what this tells us about Zimbabweans' perceptions of religious politics, that is, the deployment of conventional and dominant religions such as Christianity in politics. The article argues that, despite the separation of religion and politics being a celebrated tenet of liberal democracy in Africa, its implementation remains hotly contested. While some citizens believe in the miraculous power of prayer in politics, others call strongly for realpolitik strategies to bring about political change. Methodologically, the article is based on a digital ethnography of Chamisa's Twitter posts and the direct responses to them posted by members of the public during the fasting and prayer week. The data mined from Twitter, although restricted to this week of fasting and prayer, constitutes a rare data sample providing a vantage point from which to analyse the significance of religious politics in Zimbabwe.

On the 26th of July 2019, via a live video on Facebook, Nelson Chamisa called Zimbabweans both within and outside the country to pray for Zimbabwe between Monday 29th July and Sunday 4th August 2019 because of the deteriorating state of human security, as evidenced by the hardships the people were facing. He asked people to set aside an hour between 1 PM and 2 PM every day to pray for the power, wisdom, strength and providence to see Zimbabweans

1 At the time of writing there is contestation between Thokozani Khupe and Nelson Chamisa, who were both Vice-Presidents of the MDC-T, regarding who should have been the rightful person to assume the Presidency of the party following the death of Morgan Tsvangirai. In this article MDC refers to the party now being led by Nelson Chamisa. 
through. In his call he invoked a litany of the human security challenges that the people of Zimbabwe were enduring. This included a lack of fuel, electricity, money, passports, jobs, food, access to medical facilities or medication, children dropping out of school and companies going out of business. He therefore urged Zimbabweans from all walks of life and various denominations to embark on a seven-day period of prayer, fasting and intercession for the country. He also stated that after the prayer week he would announce crucial and decisive next steps, which were not revealed at this point; these later turned out to be nationwide demonstrations, which were subsequently banned by the state. He concluded his invitation by citing a number of Bible texts, comprising of Psalm 68:31 [Princes shall come out of Egypt; Ethiopia shall soon stretch out her hands unto God], Psalms 11:3 [If the foundations be destroyed, what can the righteous do?] and 2 Chronicles 7:14 [If my people, who are called by my name, will humble themselves and pray and seek my face and turn from their wicked ways, then I will hear from heaven, and I will forgive their sin and will heal their land]. He concluded his call with the words "I thank you, God bless you, God bless Zimbabwe, God bless Africa." ${ }^{2}$

Chamisa closed the week of prayer by thanking the people for participating and assuring them that God was on their side. He thanked the pastors, bishops and all the prophets who had accompanied Zimbabweans in the week of prayer. Harking back to the shortages, he said that there can be shortages of every commodity, but not of faith, prayer and commitment to God. He hinted at the next steps he had mentioned in the invitation to prayer, saying: "We move into the next phase of very decisive steps to be taken in peace, in non-violence, in making sure that we give effect to something that speaks to works because faith without works is dead. We now need to do the work. We have to roll up our sleeves and as a people be our own liberators, be our own answers, be our own solutions."3 In what seemed to be a language of unity, Chamisa stated that the prayer was not about ZANU PF or the MDC or any specific political party or organization. He again concluded with a Biblical quotation from Malachi 3:12: "All nations shall callyou blessed, and you shall be a delightful land."

2 Muza Mpofu, "No fuel, no power, no money, no jobs and no food: Chamisa sends this message to Zimbabweans". https://myzimbabwe.co.zw/videos-pics/49463-no-fuel-no-power-no -money-no-jobs-and-no-food-chamisa-sends-this-message-to-zimbabweans-video.html (accessed 10 August 2019).

3 ZimLive.com, Faith without works is dead, declares Chamisa after 7 days of prayer. https:// www.zimlive.com/2019/08/o6/faith-without-works-is-dead-declares-nelson-chamisa-after -7-days-of-prayer/. (accessed 10 August 2019).

4 Staff Reporter, Nelson Chamisa's message after 7 days of prayer. https://bulawayo24.com/ index-id-news-sc-national-byo-167685.html (accessed 10 August 2019). 
This article draws on a digital ethnography of Twitter, which has become an outlet for many politicians because it provides them with the opportunity to create and share ideas and information instantly, without barriers. ${ }^{5}$ Digital ethnography (also called Internet, virtual, or online ethnography) is a research method used to examine the culture of online individuals and groups. It modifies traditional ethnographic approaches and theory by applying them to the online space. ${ }^{6}$ Thus, the study of digital technology, and especially of social media, is becoming an increasingly important topic of research among scholars who study politics and its interaction with various aspects of society.

The data set analyzed in this article comprises tweets that were direct responses to Nelson Chamisa's tweets during the prayer week between 2gth July and 4th August 2019. Twitter messages can take the form of emojis, links, GIFs, photos and/or videos. I have focused on the written text responses indicated by "Replying to @nelsonchamisa". I have identified, extracted and studied responses rather than respondents because some respondents tweeted more than once but with different messages. To ensure that I was not diverted from this goal and that I was able to capture a clear overview of the responses to Chamisa, I did not include dialogues between the respondents themselves. I gathered the responses of each day in one document and coded the data set (the responses) using MAXQDA qualitative analysis software, and analysed them using deductive coding (concept- or theory-driven coding) and inductive coding (data-driven or open coding). This mixed approach to coding allowed me to focus on the main research questions without preventing me from factoring in emerging themes.

During the period of prayer and fasting Chamisa tweeted a message on a daily basis, to which people responded. I went through all the tweets for each of the seven days and coded 1,185 tweets I found to be relevant as responses to Chamisa's daily messages. Some people simply took the opportunity to say something to Chamisa; these were not coded because they were irrelevant to the objective of this article. MAXQDA gave me a statistical overview of the responses according to three categories - positive (i.e. endorsing Chamisa's call

5 Twitter, Inc. About Twitter. 2015. https://about.twitter.com/company (accessed 10 August 2010).

6 Dhiraj Murthy, "Digital ethnography: an examination of the use of new technologies for social research", Sociology 42/5 (2008), 837-855; Domínguez, Daniel; Beaulieu, Anne; Estalella, Adolfo; Gómez, Edgar; Schnettler, Bernt \& Read, Rosie, Virtual Ethnography. Forum Qualitative Sozialforschung / Forum: Qualitative Social Research 8/3 (2007). http://nbn-resolving.de/ urn:nbn:de:0114-fqso703E19. 
for prayer), negative (i.e. against Chamisa's call for prayer) and neutral (i.e. neither endorsing nor opposing the call for prayer, but making neutral comments). The analysis concluded that Chamisa's call received over $73 \%$ positive support, $22 \%$ negative support and about $5 \%$ neutral support of those who responded on Twitter. ${ }^{7}$ I was inspired to label responses around the categories positive, negative and neutral, by sentiment analysis used in the business sector; this approach uses algorithms to identify the polarity of sentiment and opinions about products - for instance, detecting the popularity of films from multiple online reviews, or diagnosing which parts of a vehicle are liked or disliked by owners through their comments to a dedicated site or forum: positive, negative or neutral. Sentiment analysis is also understood as a process of computationally identifying and categorizing opinions expressed in a piece of text, especially in order to determine whether the writer's attitude towards a particular topic, product, etc. is positive, negative or neutral. ${ }^{8}$ However, in this study, I did not do the data-mining computationally but manually. The positive, negative and neutral responses were not homogenous. Respondents were positive, negative or neutral, but not always for the same reasons. Thus, to go beyond the count-based analysis while not missing the high value insights, I also undertook a content analysis of the relevant responses to find out what themes were represented by the positive, negative and neutral categories. These themes are introduced in the findings section below.

I encountered the usual challenges of studying written internet-based data. These included contrastive conjunctions, that is, contradictions within one tweet, making it difficult to classify it as positive, negative or neutral. In some cases, it was difficult to detect sarcasm in sentences and words. In others, the analysis was challenging because of poor spelling, the use of acronyms and other abbreviations, poor punctuation and grammar. In some instances, it was not easy to differentiate between positivity, negativity or neutrality between Chamisa as an individual and the religious approach since in this case they are conflated. In some responses it was clear that the respondent was supporting Chamisa as a politician and not because of his religious approach, while in others the reverse was evident. Yet other respondents were not against the religious approach but against it at this point of time or for this purpose. Twitter is associated with brevity, which increases the use of abbreviations and acronyms,

7 Because these posts were on a publicly accessible social medium, I have opted not to anonymise the names.

8 Shashank Gupta, Sentiment Analysis: Concept, Analysis and Applications. https://towards datascience.com/sentiment-analysis-concept-analysis-and-applications-6c94d6f58c17 (accessed 10 August 2019); Bo Pang \& Lillian Lee, "Opinion mining and sentiment analysis", Foundations and Trends in Information Retrieval 1/1-2 (2008), 1-135. 
any of which might not be familiar to the analyst. To counter these challenges, I made use of the context and my experience of and familiarity with Zimbabwe to hazard a conjecture of what the respondent might be suggesting.

Religion is not only shrouded in definitional confusion, it also manifests itself in different ways on the political landscape both within and beyond Africa. This article understands religion as "lived religion", that is, religion as it is understood in everyday life, which "includes attention to rituals and stories and spiritual experiences that may draw on official religious traditions, but may also extend beyond them."9 Politicians such as Chamisa in Zimbabwe pay a great deal of attention to the spiritual world as a source of power and legitimation. ${ }^{10}$ However, the entangling of religion and politics manifests itself in different ways.

Religious politics is one of the analytical concepts that can illuminate our analysis of the deployment of religion on the political landscape by politicians in Africa in general and by Chamisa in particular, as well as providing insights into how people respond to religion on the political terrain. According to Carsten Laustsen, religious politics refers to the deployment of conventional religion - that is, the traditional religious traditions such as Christianity and Islam-in politics. ${ }^{11}$ Examples of this approach include how political actors translate religion in the conventional sense or something conventionally religious into political viewpoints and political practices. In other instances, religious parties or players derive political positions from fundamental religious dogmas. Religious politics can be traced back to or be rooted in religious

9 Nancy T. Ammerman, "Finding Religion in Everyday Life", Sociology of Religion 75/2 (2014), 189-207.

10 Sara Rich Dorman, "Rocking the Boat?' Church-NGOs and Democratization in Zimbabwe", African Affairs 101/402 (2002), 75-92; Stephen Ellis and Gerrie ter Haar, Worlds of Power: Religious Thought and Political Practice in Africa (New York: Oxford University Press, 2004); David Lan, Guns and Rain: Guerrillas and Spirit Mediums in Zimbabwe (Berkeley and Los Angeles: University of California Press, 1985), Chitando, Ezra, "In the Beginning Was the Land': The Appropriation of Religious Themes in Political Discourses in Zimbabwe", Africa: Journal of the International African Institute 75/2 (2005), 220-39.

11 Laustsen Carsten B., "Studying Politics and Religion: How to Distinguish Religious Politics, Civil Religion, Political Religion, and Political Theology", Journal of Religion in Europe 6/4 (2013), 428-463. 
scripture. The deployment of scripture is central to and characteristic of the material being analysed in this article. Those who deploy religious politics do not believe in keeping the religious indoors; religion is not merely a private matter, but one that influences or determines the formulation of political viewpoints based on religious texts. The religious is both a view of life and a world view, and thus also a matrix for formulating political viewpoints. ${ }^{12}$ This is the approach that Chamisa took by virtue of translating his Christian faith, traceable to scriptures, into political viewpoints and practices, and not keeping his faith indoors as a private matter.

Religious politics should be distinguished from "political religion", which, according to Emilio Gentile, applies when totalitarian regimes face a threat from mass democracy. The political system becomes sacralised, based on an unchangeable monopoly of power, ideological monism, and the obligatory and unconditional subordination of the individual and the collectivity to its own code of commandments. ${ }^{13}$ Political religion is used to mobilise support for a particular political program. The religious is thus primarily understood in a functionalist and instrumentalist way. ${ }^{14}$ Gentile observes that political religion "is of an exclusive and integralist character. It rejects coexistence with other political ideologies and movements, denies the autonomy of the individual with respect to the collective, prescribes the obligatory observance of its commandments and participation in its political cult, and sanctifies violence as a legitimate arm of the struggle against enemies, and as an instrument of regeneration. It either turns hostile on or seeks to co-opt or eliminate established religions." 15 Political religion assigns a subordinate and auxiliary role to established religions. ${ }^{16}$ It is much more interested in regime security than in human security. This was a common practice during the time of Robert Mugabe in Zimbabwe. ${ }^{17}$

\footnotetext{
12 Ibid.

13 Emilio Gentile, Politics as Religion (Princeton, NJ: Princeton University Press, 2006); William Cavanaugh, The Myth of Religious Violence (Oxford; Oxford University Press, 2009).

14 Tarusarira, Joram, Reconciliation and Religio-political Non-Conformism in Zimbabwe (London: Routledge); Laustsen, supra $\mathrm{n} 2$.

15 Ibid.

16 Emilio Gentile, Political religion: a concept and its critics-a critical survey, Totalitarian Movements and Political Religions, 6/1 (2005), 19-32, DOI: 10.1080/14690760500099770.

17 Tarusarira, supra $\mathrm{n} 11$.
} 
While some respondents agreed in responding to the religious approach negatively, the manner in which they did varied. As indicated above, about $22 \%$ of the respondents reacted negatively to the adoption of a religious approach to politics or to mixing religion and politics. A number of themes emerged from the data, namely "turning religious language against Chamisa", "calling on Chamisa to confess" and "negativity with some recommendations on what Chamisa should do instead".

\subsection{Turning Religious Language against Chamisa}

Because Chamisa was using religious language to mobilize his followers, also some of those who reacted on Twitter against this approach turned to religious language to challenge or oppose him. This gave them an opportunity to express their understanding of the interaction between religion and politics. Some believed that everything happens for a reason and that therefore the current political status quo can be considered as God's plan. This should not necessarily be read as an endorsement of the current political leadership, but as a view that the current leadership has to be obeyed because scriptures call for obedience of the nation's leadership. The following tweets represent this line of thought.

You should be praying for your leaders so God can give them wisdom to lead you peacefully well, I Timothy 2:1-2, not to unseat them for Titus 3: 1-2 speaks of submission and obedience to the rulers God has put in those places [sic]. ${ }^{18}$

[...] respect of the current leadership is still a requirement. David never wished bad on Saul even though it was pretty obvious that he wanted him dead. Leaders are anointed by God and him alone. ${ }^{19}$

And his will prevails no matter your desires for God knows what is best for you @neslonchamisa and what is good for his people the

18 Dee M. Twitter, 31 July 2019. https://twitter.com/search?q=You\%2oshould\%2obe\% 2opraying\%2ofor\%2oyour\%2oleaders\%20so\%20God\%20\&src=typed_query (accessed o1 August 2019).

19 PR, Twitter, 31 July 2019. https://twitter.com/search?q=respect\%20of\%2othe\%20 current\%2oleadership\%2ois\%2ostill\%20a\%2orequirement\&src=typed_query (accessed 01 August 2019). 
Zimbabweans no matter how desperate you are to be President, it looks like the Lord has other ideas and his choice is His. ${ }^{20}$

Yet others were explicit in their support of Emmerson Mnangagwa, the current President of Zimbabwe, famously referred to as ED, considering him as the one chosen by God, and they indicated that they were going to support him. In these Tweets, religious language was turned against Chamisa in direct support of Mnangagwa. Chamisa's religious authority was also questioned in the process. Responses to this effect included the following:

I pray that God help ED because planning is his, if he had seen it not fit for him to be the leader, it would not have happened that way. My prayer is God guide ED, give him wisdom, protect him because kingship comes from you ... bless Zimbabwe, bless ED. ${ }^{21}$

True men of God will not talk of demonstrations and uprisings, that's ungodly, the will of God is what is happening now, your idea wanting the people of Zimbabwe to suffer so that they will rise up against the government will not work. God allowed ED to rule and that is his plan. ${ }^{22}$

\subsection{Calling on Chamisa to Confess}

In his introductory message on the first day, Chamisa called for confession and the forgiveness of sins. This too was turned against him, as he himself was called on to confess. Three allegations dominated the reasons why he was asked to confess, namely his "calling for sanctions", "perpetrating violence" and "selfish tendencies, including love of power".

Responses that indicated the call to "confess for the sanctions" include the following:

20 Musa Kasamba, Twitter 31 July 2019. https://twitter.com/search?q=And\%2ohis\%20 will\%2oprevails\%2ono\%2omatter\%2oyour\%2odesires\%2ofor\%2oGod\&src=typed_ query (accessed o1 August 2019).

21 Enzo, Twitter, 31 July 2019. https://twitter.com/search?q=nekuti\%2okuronga\%20 ndekwavo\&src=typed_query (accessed or August 2019).

22 Jmag43, Twitter, 04 August. https://twitter.com/search?q=True\%2omen\%2oof\%20 God\%2owill\%2onot\%2otalk\%2oof\%2odemonstrations\%2oand\%2ouprisings\& src=typed_query (accessed 05 August 2019). 
The biggest prayer you can have is to call for the removal of sanctions that have crippled this country. ${ }^{23}$

Pastor, I think you must repent for calling for sanctions, its evil and wickedness in the eyes of God. God knows and he sees, your supporters can cheer you all the way to hell, but God is not mocked. Years ago, thousands of USD from Australia were forfeited because of my surname."24

[...] when are you going to confess for causing the unnecessary deaths of Zimbabweans over sanctions you went to the USA to beg for? A sell out should confess. ${ }^{25}$

There is no sin that is outdone by another sin, if you really want God to answer your prayers remove those sanctions which you called for in order to cripple the economy. ${ }^{26}$

Your hands are not clean at all, you called for sanctions and supported them to the extent of going to America to plead with them not to remove sanctions until you are in power, many people have died as result of sanctions. If you go to the grave yards, those graves are the evidence. ${ }^{27}$

Tweets that called for Chamisa to confess for allegedly "being a violent leader" included the following:

The first thing to do is to go down on your knees and confess your own sins Wamba [Chamisa's nickname]: Tsvangirai family abused for power; Khupe and company nearly burnt and bashed for power; you lied far too many times; your treatment of women as objects; the blasphemy you are currently on. ${ }^{28}$

God will only answer your prayers positively when you are loyal and loving person and you are not. You are full of hate and insults. Did you ask

23 National vision, Twitter, 3 August 2019. https://twitter.com/Nationalvision6/status/ 1157665491269443584 (accessed 04 August 2019).

24 BlessingMakoni,Twitter4August 2019.https://twitter.com/search?q=Pastor\%2C\%20I\%20 think\%20you\%2omust\%2orepent\%2ofor\%2ocalling\%2ofor\%2osanctions\&src=typed_ query (accessed 5 August 2019).

25 Wayfarer, Twitter 29 July 2019. https://twitter.com/search?q=when\%2oare\%2oyou\%20 going\%20to\%2oconfess\%2ofor\%2ocausing\%2othe\%2ounnecessary\%2o\&src=typed _ query (accessed 30 July 2019).

26 Tatenda, Twitter 31 July 2019. https://twitter.com/Tatendao7398234/status/ 1156381726693908480 (accessed o1 August 2019).

27 Jmg43, Twitter 29 July 2019. https://twitter.com/jmaj43/status/1156794743768195083 (accessed 30 July 2019).

28 Nevanji, Twitter 31 July 2019. https://twitter.com/NNehoreka/status/1156444845227040768 (accessed o1 August 2019). 
for forgiveness ... You just want power? You shall never be President of Zimbabwe. You like violence. ${ }^{29}$

"On day 1 you said sins need to be confessed." Remember that 1st of August happened as a result of leaders announcing that they had won, with evidence and the votes were stolen ... leaders must not announce things they have no backing for because it agitates the youths $[\ldots] .{ }^{30}$

The third allegation for which Chamisa is called upon to confess is "being a selfish person who loves power, no matter what it takes". Responses to this were as follows:

Truly I say to you, you cannot stand in front of people calling God's name, saying your hands are clean, we know that the MDC used to dispatch a lorry in the evening full of your so-called vanguard, to go as far as Mutoko to terrorize, yet would cry louder the next morning. ${ }^{31}$

I know you are personally doing this [calling for prayer] for power, but please apologize to the electorate for lying to them a couple of times. Man up and face your fears, truth, honesty and transparency [...]. ${ }^{32}$

I remember when RGM [Robert Gabriel Mugabe] was still in power. I followed you on Facebook when you would show your lives sessions daily. I hoped and prayed you would be our next leader. As soon as MRT [Morgan Richard Tsvangirai] died, that side of you died too. You became something else. Your lies and deception put me off. ${ }^{33}$

\subsection{Negative with Recommendations}

Other responses were not only negative about the religious approach but also offered recommendations as to what might be the way forward. Four aspects dominated the recommendations. First, Chamisa should enter into a dialogue with Emmerson Mnangagwa (the current president). Secondly Chamisa must lead real actions, such as demonstrations. Thirdly he should separate religion

29 Sam Mpofu, Twitter o1 August 2019. https://twitter.com/MpofuSam/status/11580694 52501655556 (accessed o2 August 2019).

30 Ashereni, Twitter 02 August 2019. https://twitter.com/search?q=On\%2oday\%201\%20 you\%2osaid\%2osins\%2oneed\%2oto\%2obe\%2oconfessed\&src=typed_query (accessed 03 August 2019).

31 Zimbabwe my country, Twitter o1 August 2019. https://twitter.com/ZCountry/status/ 1156800684165128197 (accessed 02 August 2019).

32 Chomsino, Twitter o1 August 2019. https://twitter.com/Chillaz87/status/115678674 6325159936 (accessed 02 August 2019).

33 Pro-africa, Twitter, o1 August 2019. https://twitter.com/zw_shumba/status/115679 6709416177664 (accessed o2 August 2019). 
and politics, while lastly he should be inclusive in his approach, realizing that Zimbabwe is a multi-religious country.

On the issue of dialoguing with Mnangagwa, responses included the following: "To be honest with you, it does not need fasting and prayer, but just go for dialogue. Why are you refusing to hold a dialogue with the others? That arrogance of yours will make you lose 2023 elections again"; 34 "Go and dialogue with ED";35 and "Mr. Chamisa, the situation in our country has reached another level to the extent that prayer is not enough. All it takes is just a phone call to your brother ED and talk, just that."36

Those who called for action felt that prayer was either not the right action at this point in time or not a right action at all when it comes to politics. What they wanted to see were real political actions, including demonstrations and even civil unrest. This was expressed as follows: "Zimbabwe ndeyeropa (Zimbabwe is born of liberation struggle blood). For things to be fine blood has to be spilt", 37 "stop advocating for prayer. Strategize ...,",38 "Zimbabwe now needs war ... verses and tweets will achieve nothing. Stop this nonsense", 39 "Let us be serious as leaders please, this fasting won't bring change to Zimbabwe." ${ }^{40}$

Another conspicuous theme against the religious approach to politics was a clarion call to separate religion from politics. This represented the thinking that the two do not go together and that religion was being abused for political ends. This was expressed in the following responses: "Politics and Religion don't mix, so let's decide what we want to be first ... Politics is a dirty game as they say, God is clean ... lets be true to ourselves first, God is not to blind",41 "Your politicization through religious gimmicks is now exposed, the Bishop

34 Elijah Chihota, Twitter, 30 July 2019. https://twitter.com/ChihotaElijah/status/1156195 208981356545 (accessed o1 August 2019).

35 Chibanki, Twitter, 3 August 2019. https://twitter.com/chibangetk/status/1157558341 868167168 (accessed 4 August 2019).

36 Muvhimwa, Twitter, o1 August 2019. https://twitter.com/edmunjodzi/status/1156 801998399975424 (accessed 02 August 2019).

37 Shady Maruta, Twitter, 30 July 2019. https://twitter.com/MarutaShaddy/status/1156o 81992687136768 (accessed 31 July 2019).

38 Jp vundla, Twitter,o1 August 2019. https://twitter.com/JbVundla/status/115682225 2773621760 (accessed o2 August 2019).

39 Not another 100 years of "BLACK" minority rule, Twitter, 04 August 2019. https://twitter .com/PercyPakati/status/1157922585490989056 (accessed 05 August 2019).

40 Obed, Twitter, 30 July 2019. https://twitter.com/Obbiemashy/status/1156110265789886465 (accessed 31 July 2019).

41 Easyway Muchunga, Twitter, 31 July 2019. https://twitter.com/easym935/status/ 1156456326899347456 (accessed, or August 2019). 
Abel Muzorewa. ${ }^{42}$ Separate the two", ${ }^{43}$ "Now you have started engaging the scriptures which you don't know, concentrate on politics and leave the Bible alone",44 "How serious are you? This is Politics Not Religion?",45 "Maybe you should have been a Pastor rather than a leader of an Opposition party. These two must be separated. God gives us different callings, we can't have an opposition leader who is as soft as wool, consider swapping careers", 46 "Comrade don't conflate Christianity and Politics", 47 "I just hate it when politicians mix religion and politics"48 and "You should be a Pastor not the President of Zimbabwe. This your idea of people relying on Jesus for economic reform in Zimbabwe is stupid." 49

The last type of recommendation is that Zimbabwe is not religiously monolithic. According to some tweets, Chamisa does not seem to pay attention to the fact that Zimbabwe has not only Christians, but also African religious practitioners, Muslims, Jews and followers of Baha'i, regardless of how few they are. This was expressed in the following tweets: "How about those citizens who are other religions?", 50 "so, when you put this as a Christian you do not think other supporters who are non-Christians and believe in other religions?", and "You are fasting for the land of Chaminuka and Nehanda in the name of Jesus? Brew beer to your ancestors." ${ }^{51}$

42 Bishop Abel Muzorewa was a United Methodist Church bishop and the founder of the United African National Council who, after striking a deal with the colonial administration led by Ian Smith, served as Prime Minister of Zimbabwe-Rhodesia from the Internal Settlement to the Lancaster House Agreement in 1979.

43 Albert Nyaude, Twitter, o3 August 2019. https://twitter.com/bheshto/status/1157526595 827130369 (accessed 04 August 2019).

44 Princhando, Twitter, 03 August 2019. https://twitter.com/princhando/status/11575420 81717579776 (accessed o4 August 2019).

45 Chibanki, Twitter, 04 August 2019. https://twitter.com/chibangetk/status/1157906976 023732225 (accessed 05 August 2019).

46 Abed, Twitter, o1 August 2019. https://twitter.com/baaddubs/status/1156897028938620928 (accessed 05 August 2019).

47 Kudakwashe Chikwanda, Twitter 03 August. https://twitter.com/chikwandakb/status/ 1157518579388080131 (accessed 04 August 2019).

48 Bigkahuna, Twitter, 02 August 2019. https://twitter.com/wepasavannah/status/11573 86055483645953 (accessed o3 August 2019).

49 Johnny Greg, Twitter, o4 August. https://twitter.com/johnnygreg_sa/status/115792448213 8476545 (accessed 05 August 2019).

50 Torito, Twitter, 03 August. https://twitter.com/IaM_Torito/status/1157517228570550273 (accessed 04 August 2019).

51 ChixChico, Twitter, 02 August 2019. https://twitter.com/chix_chico/status/115717734 7092692992 (accessed o3 August 2019). 
The positive responses were of three types, namely simple and short statements, scriptural citations, and recommendations. Characteristic of those who supported the religious approach to politics was the brevity of the responses, the simple response "Amen" being the most frequent. According to other responses, "There is no name like Jesus. No situation is permanent. On our knees are the answers",52 "\# Pamabvihatibvi" [translated-we will remain on our knees praying], "Amen God is in it", "\#Godisinit", "Aluta continua, we are praying", 53 "When Jesus says yes nobody can say no, it's day two dear ones", 54 "Together we will conquer, with Jesus we believe",55 "\# GodblessZimbabwe", 56 "I did join you today. Pamabvi hatibvi", 57 "We are in it, praying for our country, praying for the future of our children. God hears and answers prayers" ${ }^{\prime 5}$ and "The Lord will lead us to a new Zimbabwe". ${ }^{59}$ Other short but positive responses mentioned Nelson Chamisa by name or title. These include: "Prayer changes things ... Prayer changes people ... thank you Mr Chamisa for this call",60 "I love you my President (sic), Zimbabwe will see the power of prayer", "We are solidly behind you Mr President."61

\subsection{Political Responses through the Scriptures}

Also tweets that responded positively to Chamisa's call for prayer and fasting made liberal use of religious language; many of the tweets included references

$5^{2}$ Ndimba, Twitter, 30 July. https://twitter.com/ZakeyoZak/status/1156057224323747842 (accessed 31 July 2019).

53 William Zambezi, 30 July 2019. https://twitter.com/williamzambezi/status/11560669o3 846264832 (accessed 31 July 2019).

54 Ndimba, Twitter, 30 July 2019. https://twitter.com/williamzambezi/status/1156066903 846264832 (accessed 31 July 2019).

55 Miriam Katanayi, Twitter 30 July. https://twitter.com/TakanayiMiriam/status/11559 85470553088006 (accessed 31 July 2019).

56 Bobi, Twitter, 30 July 2019.

57 Yeukai Mutemaringa, Twitter 30 July 2019. https://twitter.com/YMutemaringa/status/ 1156055294759395329 (accessed 31 July 2019).

58 Simon Gwenzi, 30 July 2019. https://twitter.com/SimonGwenzi/status/11561143969 86429440 (accessed 31 July 2019).

59 Memo, Twitter 31 July 2019. https://twitter.com/Memobere/status/1156426875662688256 (accessed o1 August 2019).

6o Flicko, Twitter, 30 July 2019. https://twitter.com/AnywayMagonyo/status/1156192588 682207234 (accessed 31 July 2019).

61 Liberty Mushonga, Twitter, 31 July 2019. https://twitter.com/Gerry8536979o/status/ 1156430589098110976 (accessed o1 August 2019). 
to Biblical passages. I gathered a large number of Biblical verses used in responses to support the move by Nelson Chamisa to pray and fast, which I interpreted sociologically and not theologically. That is, I did not endeavor to establish the veracity of the scriptures or the "correct" theological interpretation of the Biblical citations, but rather organized them according to themes. Numerous tweets hinted at how the respondents understand that God 'works'. Several respondents referred to Matthew 18:19: "Again, truly I tell you that if two of you on earth agree about anything they ask for, it will be done for them by my Father in heaven"; thus indicating the importance of collective action in prayer. This might explain why Chamisa called for a collective prayer, instead of him praying and fasting alone. Other tweets from the respondents referred to Mark 11:24; the words "Therefore I tell you, whatever you ask for in prayer, believe that you have received it, and it will be yours" were cited to stress not only the importance of collective prayer, but also the confidence that God answers prayers.

Other responses suggested that God appointed Chamisa to superintend the governance of Zimbabwe. Respondents cited verses such as Jeremiah 1:10: "see, today I appoint you over nations and kingdoms to uproot and tear down, to destroy and overthrow, to build and to plant" and Deuteronomy 1:21, "see, the Lord your God has given you the land. Go up and take possession of it as the Lord, the God of your ancestors, told you. Do not be afraid; do not be discouraged." Noteworthy: A divine appointment is highly respected in the context of Zimbabwe, for it sacralizes and legitimates the appointed, thus shielding him/ her from negative criticism; to criticize the appointed would be to challenge the appointing authority, in this case the omniscient God.

On the first day of prayer and fasting Chamisa presented his call for a week of confession and forgiveness as a precondition for the actions that were to follow. This logic was picked up by some respondents, who cited verses such as Matthew 6: 33, which reads: "But seek first his kingdom and his righteousness, and all these things will be given to you as well", and John 1:9, "If we confess our sins, he is faithful and just and will forgive us our sins and purify us from all unrighteousness". These tweets (and verses) seem to suggest that, in order to receive God's favor, the first order of business is to seek him and be righteous before him. Chamisa's actions also seemed to have followed this logical framework, because, following the prayer week, he announced that the MDC was going to hold demonstrations to protest against the deepening economic crisis and hardship in Zimbabwe. In the light of the verses cited above, in retrospect, the prayer and fasting week might therefore be perceived as a preparation for this action. A successful action, in this case a demonstration, is to be launched, provided Zimbabweans seek the kingdom of God first. 
Those who attributed the present economic hardships in Zimbabwe to the current leadership quoted Proverbs 29:2: "When the righteous are in authority, the people rejoice: but when the wicked beareth rule, the people mourn". By doing so, these tweets seem to suggest that Chamisa is the righteous leader who, if put into office, will make Zimbabweans rejoice. Humbly submitting to God and being righteous was also seen a precondition for obtaining God's favor. According to some respondents, this was what Chamisa was doing by calling for the week of prayer and fasting. To emphasize this perception, some respondents cited 2 Chronicles 7:14: "If my people, who are called by my name, will humble themselves and pray and seek my face and turn from their wicked ways, then I will hear from heaven, and I will forgive their sin and will heal their land". Others invoked God's omnipotence by citing Isaiah 41:10: "so do not fear, for I am with you; do not be dismayed, for I am your God. I will strengthen you and help you; I will uphold you with my righteous right hand". The respondents seem to suggest Chamisa was not to fear anything because the all-powerful God was with him and would protect him. Citing 2 Chronicles 20: 15, "He said: 'Listen, King Jehoshaphat and all who live in Judah and Jerusalem! This is what the Lord says to you: "Do not be afraid or discouraged because of this vast army. For the battle is not yours, but God's", also expressed such sentiments.

Such language of hope and strength also emerged from other responses. In some tweets Zimbabweans were encouraged not to lose trust in God because of the current suffering. The tweets advised Chamisa and Zimbabweans to identify with Jesus, who suffered but eventually conquered. To support this perception some tweets cited 2 Corinthians 4: 8-10: "We are hard pressed on every side, but not crushed; perplexed, but not in despair; persecuted, but not abandoned; struck down, but not destroyed. We always carry around in our body the death of Jesus, so that the life of Jesus may also be revealed in our body."

\subsection{Positive Responses with Recommendations}

Other responses were positive but also presented recommendations to Chamisa, which, unlike the responses of those who were negative about religious politics, centered on adding practical actions to prayer. Notable is the fact that the call to action was also made by those who were negative about the religious approach to politics. These respondents were not against prayer, but wanted it to be complemented by action. These responses included the following: "It is fine to pray but what is required are modern political strategies and tactics to get Zimbabwe on the right path", 62 "Prayers yes, but the situation

62 PR, Twitter 30 July 2019. https://twitter.com/MozalionessPr/status/1155980535950278656 (accessed 31 July 2019). 
now requires action, we are ready to fight them back bring guns", 63 "After the prayers let's do it Mr. President", ${ }^{64}$ "Day 7/7 fasten your seat belts", ${ }^{65}$ "Last day of fasting, now waiting for the next crucial and decisive step Mr. President", 66 "Last day of prayer. Tomorrow let's see action",67 "Even in the Bible prayers without action truly never brought any redemption",68 and "You must pray and then take action". ${ }^{69}$

\section{7}

Neutral Responses to Chamisa's Message

Neutral responses included those that were either clearly neutral regarding the religious approach to politics or that were difficult to categorize as either positive or neutral. The latter in some cases reflected the methodological challenges of studying internet-based written data, including the failure to detect sarcasm. However, this challenge did not influence the overall picture of how Chamisa's call for a week of prayer and fasting was perceived. Such posts include the following: "Don't miss-fire after counting 7 full days",70 "Confidence has been restored hopefully the decisive next step is there and not tomfoolery",71 "What happens after prayer and fasting?", 72 "Hello papa",73

63 Noel obrian dale, Twitter 30 July 2019. https://twitter.com/ObrianNoel/status/1156074915 809976320 (accessed 31 July 2019).

64 Alfred, Twitter 03 August 2019. https://twitter.com/AlfredChipfaka1/status/11575579 93946435584 (accessed 04 August 2019).

65 Ndimba, Twitter 04 August 2019. https://twitter.com/ZakeyoZak/status/1157866o9 8416660480 (accessed o5 August 2019).

66 @takundakofa, Twitter 04 August 2019. https://twitter.com/takundakofa/status/115791 8949331406854 (accessed o5 August 2019).

67 Nkoccie Muckquattie, Twitter 04 August 2019. https://twitter.com/MakwatiNkosi/status/ 1157862078117494785 (accessed 05 August 2019).

68 Mwana, Twitter 04 August 2019. https://twitter.com/RmamoyoRuru/status/1157881 750829379584 (accessed o5 August 2019).

69 Trevor Tshuma, Twitter o1 August 2019. https://twitter.com/tretsh85/status/11567815 43936991234 (accessed 02 August 2019).

70 Trevor Tshuma, Twitter 30 July 2019. https://twitter.com/tretsh85/status/1156200311 574454274 (accessed 31 July 2019).

71 Taps, Twitter 30July 2019. https://twitter.com/TapiwanarTaps/status/1156072759958671366 (accessed 31 July 2019).

72 Sir-Don, Twitter 31 July 2019. https://twitter.com/SirDonkhumalo/status/1156421123 397038081 (accessed o1 August 2019).

73 Tapiwanashe loftus the master, o1 August 2019. https://twitter.com/Tapiwamhaka1/ status $/ 1156780884550443008$ (accessed o2 August 2019). 
"Just wondering what you are gonna do on Monday, action or another tweet?",74 "24 hours to go",75 "Maverse tamboverenga, thanks" [translated: We have indeed read quite a lot of verses, thanks],76 "What time are we breaking the fasting Mr. President?", 77 "President am so sad"78 and "Boss. What happens on Day 8". ${ }^{79}$ What is arguably clear from the preceding tweets is that they are ambivalent, being interpretable as suggesting support or otherwise.

\section{Discussion: the Ambivalence of Religious Politics}

This article has set out to study how Chamisa's call for a week of prayer was received by those who responded to his Twitter messages; the article investigated what the responses tell us about Zimbabweans" perceptions of adopting a religious approach to politics and their understanding of the definition and function of religion in politics. The findings show that in general Zimbabweans respond positively to Chamisa's approach: over $73 \%$ of the responses were positive. Among those that were positive were those suggesting that prayer needs to be complemented with real practical action such as demonstrations. This finding is in step with the understanding that religion is important in Zimbabwe. A generous $75 \%$ of the Zimbabweans claim to be Christians. ${ }^{80}$ The numerous Biblical verses that were cited in support of Chamisa attests to this predilection.

Two aspects require particular consideration here. First of all, the tweets reference religion from a standpoint of faith, rather than from a sociological functionalist viewpoint; they do not so much focus on the sense of belonging,

74 Jnr Musevererwi1st, Twitter o3 August 2019. https://twitter.com/DMureverwi/status/ 1157572266877566977 (accessed o4 August 2019).

75 Real Buffalo, Twitter o1 August 2019. https://twitter.com/realbuffallo/status/11575971 77000144901 (accessed 02 August 2019).

76 Thiago kastlin, Twitter o3 August 2019. https://twitter.com/tawanda_kasamba/status/ 1157603131951407105 (accessed 04 August 2019).

77 Wayne Marimo, Twitter 29 July 2019. https://twitter.com/MarimoWayne/status/1155 735290008494080 (accessed 30 July 2019).

78 Farai Waini, Twitter, 02 August 2019. https://twitter.com/WainiFarai/status/1157323 681565163522 (accessed o3 August 2019).

79 GTK, Twitter o1 August 2019. https://twitter.com/kunakitov/status/1156825837162967040 (accessed o2 August 2019).

8o Tarusarira, supra n 11; Ezra Chitando and Joram Tarusarira, "The Deployment of a 'Sacred Song' in Violence in Zimbabwe: The Case of the Song 'Zimbabwe Ndeye Ropa Ramadzibaba' (Zimbabwe Was/is Born of the Blood of the Fathers/ancestors) in Zimbabwean Politics," Journal for the Study of Religion 30/1 (2017), 5-25. 
networks and structures that religion provides, but attest to the fact that the respondents believe in religion's miraculous power to effectuate change. The responses seem to indicate that the respondents think that the language deployed is believed to have performative force, that is, the ability to "do things with words". In this case they have an intrinsic agency to affect the wishes of those who utter them. Performative language, like "Amen" and "\#Godisinit", is not susceptible to evaluation as either true or false. ${ }^{81}$ Apart from these short phrases, the majority of the positive respondents cited the Bible, without any personal commentary. The use of short phrases, which is common among Pentecostal Charismatic believers in Zimbabwe, and the citing of the Bible without further commentary suggest that, for the respondents, no explanation is needed when it comes to religious language and the word of God (because it is performative language and familiarity with the texts is presumed). Second, are the responses of those who were negative and did not believe in the performative power of citing the word of God, at least not with regard to this situation and/or to when it comes to politics. The latter's responses were more passionate and longer because, unlike those who believe in the performative force of words, they needed to explain why resorting to the miraculous power of prayer was not the right thing to do. Also, among the positive responses, however, were those that believed that God's power needed to be complemented with human action. Respondents to the call for prayer comprise those who believe in the deployment of prayer and those who are against it in politics. According to the Tweets, the numbers of those who supported the use of prayer in politics were higher than those who were against it. This might suggest that Zimbabweans in general are positive to religious politics, a situation which can be useful for mobilization of supporters. This shows us that, while religious politics can elicit responses from a standpoint of faith, it can also invoke sociological benefits as a mobilization strategy.

The negative responses are illuminating when it comes to the ambivalence and volatility of religious politics. Some respondents imitated Chamisa's use of religious language, but did so in support of his main political rival, Emmerson Mnangagwa. The precariousness of religious politics also became evident when certain respondents turned Chamisa's call for confession and the forgiveness of sins against him. He was called upon to confess for allegedly calling for the sanctions which have caused the deaths of many Zimbabweans, for causing the deaths of people during the protests in connection with the announcement of the election results on 1st August 2018, and for selfish tendencies, including a hunger for power. The Chamisa-case therefore

81 Austin, John L., How to do things with words (Cambridge, MA: Harvard Univ. Press, 1962). 
evidences that religious language deployed in religious politics is susceptible to multiple interpretations.

Responding to Chamisa's call for prayer by Twitter also proved to be an opportunity for people to express their political ideas. These responses give insight in some of the sensitive political issues, such as sanctions, violence and the political dialogue in Zimbabwe's current political landscape, which political actors ignore at their own peril. One such issue is the fact that Chamisa is being called upon to stop the campaign for prayer and fasting and engage in dialogue with Mnangagwa, as well as participate in the current political dialogue among the country's political parties. This has to be understood in the context of the on-going multi-party-political dialogue called for by Emmerson Mnangagwa, the current president. This dialogue, according to Mnangagwa, is supposed to constitute a platform to facilitate reconciliation following the elections, which were contested by opposition parties, among which the MDC; the rejection of the results has been taken up at the level of the constitutional court. Other opposition parties that participated in the Presidential elections accepted the invitation to this dialogue, but the MDC turned it down, for fear of being seen to endorse an allegedly fraudulent election result. MDC's condition for participation is that the dialogue should be facilitated by an independent person or institution and not by someone allegedly associated with the Mnangagwa, who is therefore part of the electoral dispute.

The plea that religion and politics should be separated is another conspicuous issue raised by those who are negative about religious approaches to politics. One respondent wrote: "I just hate it when politicians mix religion and politics". The separation of religion and politics is a perennial question in the discourse and practice of religion and politics. Liberal secularists are opposed to any alliance between religion and politics on the grounds that religion is perceived as sectarian, and thus as divisive; with the advent of modernity, influenced by the Enlightenment, religion was perceived as irrational, absolutist and divisive. ${ }^{82}$ Secularism was affirmed as the best framework for governing public affairs, as it was claimed to be neutral, objective and universal. This, however, has proved to be a myth because from a functional point of view secularism as a framework seems to have the same inadequacies as religion. The responses however, showed strong sentiments in favor of the separation of the two. This scenario puts Chamisa in a quagmire which he has not addressed. His claims to be a modern liberal democrat suggest that he should not be pushing a religious politics, as is expected of modern liberalists. On the other hand,

82 See William Cavanaugh, The Myth of Religious Violence (Oxford: Oxford University Press, 2009), 5 . 
this might be a demonstration of the fact that this separation of religion and politics is an imposition on the electorate or that this claim of modernity does not seem applicable to the Zimbabwean context. In many African contexts religion and politics have been and remain intertwined. A concrete example are the chiefs in some parts of Africa, who are both political and religious leaders who intercede with the ancestors on behalf of the chiefdom in times of crises such as drought.

The mention of ancestors leads us to another aspect that is raised by those who contest Chamisa's religious politics. This theme speaks to a broader theme of religious diversity in Zimbabwe. Chamisa's call for prayer and fasting does not seem to consider Zimbabwe as a multi-religious country. In both his invitation and his concluding messages, he explicitly mentions denominations and thanks pastors, bishops and prophets, an indication that he is mainly addressing the Christian community. The fact that Chamisa does not mention African religions comes as no surprise because one of the fundamentals of Pentecostal Charismatic Christianity, to which he belongs, is to break away from African religions. Nonetheless, I do not claim that Chamisa is categorically averse to African religion, which in any case is difficult to deduce from his tweets.

Chamisa's explicitly Christian religious politics and how it impacts on non-Christians are not matters he has addressed, and he seems to see them as inconsequential. But given that, even though many Zimbabweans claim to be Christians, and belief in African religions remains strong, Chamisa might be expected to articulate a view on this if he wants to be a president for all Zimbabweans. African religions have interacted with politics since the liberation struggle, and traditional leaders who are custodians of religion and culture remain significant actors in Zimbabwean politics. His emphasis on Christian practices such as prayer and fasting, in a context where African religion is rife, might be considered exclusive, as responses to his tweets cited above have indicated. His approach reveals that his understanding of religion and God is restricted to Christianity.

\section{9}

\section{Conclusion}

This study has shown that religious politics remains strong and influential within Zimbabwe. In his call for a week of prayer and fasting, Chamisa explicitly made use of Christianity as part of his politics. The majority of those who responded to Chamisa's message for a week of prayer and fasting and his subsequent daily tweets, were positive of his religious approach to politics. Those who were positive, often responded with performative language reflected in 
the very short phrases or words they responded with. In general, this shows that, assuming that the respondents are Zimbabweans or of Zimbabwean origin, a religious approach to political mobilization might be well received by Zimbabweans. However, the responses also showed that the use of religious politics is more ambivalent than this majority acclamation would seem to suggest. There were others who were critical about Chamisa's call for prayer and fasting; these respondents called for realpolitik rather than prayer and fasting. Among the issues mentioned by the respondents were the sanctions against Zimbabwe imposed by the United States and the violence, both of which he and his party are alleged to be responsible for. Some respondents called on Chamisa to consider dialoguing with the current President Emmerson Mnangagwa, while others wanted action such as demonstrations rather than prayer, to put pressure on the current government. Many of the respondents that were critical about Chamisa's call for prayer and fasting, argued that religion and politics should be separated. These concerns require Chamisa's attention because people who were negative regarding the religious approach to politics for these reasons were quite strong and passionate, suggesting that these are key tools of political mobilization.

More generally, the study has evidenced the risks involved in the use of religious politics. While the majority of the respondents reacted positively, others turned Chamisa's strategy against him, using religious politics to either criticize Chamisa's past politics or to support his political opponents. The article also made clear that in multi-religious nation states, religious politics that draws on one particular religious tradition (in this case: Christianity) is at risk of alienating part of the electorate. Religious politics therefore proves to be a risky choice, even in an overtly religious country like Zimbabwe. 